O Open Access Full Text Article

\title{
Assessment of Knowledge, Attitudes, and Practice of Community Pharmacists Regarding Weight Reduction Agents and Supplements in Aseer Region, Saudi Arabia
}

This article was published in the following Dove Press journal:

Risk Management and Healthcare Policy

\author{
Sultan M Alshahrani (D) \\ College of Pharmacy, King Khalid \\ University, Abha, Saudi Arabia
}

Correspondence: Sultan M Alshahrani College of Pharmacy, King Khalid University, Abha, Saudi Arabia

Tel +966508747473

Email shahrani@kku.edu.sa

\begin{abstract}
Purpose: This study investigated the knowledge, attitudes, and practice of community pharmacists regarding weight reduction products in Aseer region, Saudi Arabia.

Materials and Methods: A questionnaire-based study of community pharmacists in Aseer region, Saudi Arabia, was conducted between March and May 2019.

Results: The most commonly prescribed weight reduction agent was green tea followed by oatmeal products and ginseng. The results revealed that almost $85 \%$ of the respondents did not know which weight reduction agents are approved as over-the-counter products by the US Food and Drug Administration. Community pharmacists had positive attitudes toward the safety and efficacy of weight reduction products, but $64.91 \%$ indicated that they would limit weight reduction agents to obese patients who could not reduce their weight through exercise and diet. More than $80 \%$ of the participants agreed that it is very important to counsel patients regarding weight reduction products, and more than $80 \%$ also agreed that pharmacists should regularly discuss weight reduction products with other healthcare professionals. Conclusion: Community pharmacists showed positive attitudes and efficient practice towards prescribing weight reducing products. However, there was a deficit regarding the knowledge about which products approved by FDA to manage overweight. That requires to consolidate the role of community pharmacists in weight management in Saudi Arabia with more continuous education and regulation.
\end{abstract}

Keywords: weight, community pharmacists, obesity, survey, Saudi Arabia

\section{Introduction}

Being overweight and obesity are defined as excessive fat accumulation that may affect normal daily activities. ${ }^{1}$ Obesity is highly acknowledged as epidemic and a public health threat. Obesity is described as a disease nowadays, and obese people are at high risk of serious secondary diseases such as hypertension, diabetes mellitus type 2, dyslipidemia, metabolic syndrome, cardiovascular diseases, and certain cancers. ${ }^{1-5}$

The obesity prevalence in developing and developed countries is steadily increasing due to lack of exercise (sedentary lifestyle) and the presence of easily accessible processed fast food almost everywhere. It has become the fifth leading cause of mortality worldwide. ${ }^{6,7}$ In Saudi Arabia, multiple recent studies have shown that the increase in the prevalence of overweight and obese people is related to modern lifestyles involving 
increased daily animal consumption instead of the consumption of organic food, fruits, and vegetables. ${ }^{8,9}$

Dietary supplements are products containing one or more dietary ingredients such as vitamins, extracts, and herbs. They are intended to supplement a normal diet by adding certain nutritional value. ${ }^{10,11}$ The clinical effects of most of these supplements have not been sufficiently evaluated in double-blinded, randomized clinical trials. Although small preclinical studies may report that dietary supplements and over-the-counter (OTC) weight reduction products reduce weight through various mechanisms of action, the vast majority of these products lack sufficient evidence when considering the whole picture, including the purity grade, effects on other health-related conditions, food-drug interactions, and potential side effects. ${ }^{12,13}$

Self-medication in Saudi Arabia is a common practice. Several studies show that OTC products and herbal remedies are widely used to treat diabetes, epilepsy, obesity, and to manage pain episodes. ${ }^{14-17}$ Community pharmacies are considered to be important providers of weight reduction products and supplements as they provide easy access to healthcare providers with zero waiting time. This situation has made dietary supplements and OTC weight reduction products easily accessible to the general population. ${ }^{17-20}$

The unlicensed weight reducing products have been an alert for long time in Saudi Arabia. The Saudi Drug and Food Authority (SFDA) keeps fighting the presence of such unlicensed and adulterated products in Saudi market. Most of these products contain high percentage of sibutramine (a restricted pharmaceutical agent) which being sold by unlicensed centers and vendors. ${ }^{21}$

This study assessed the knowledge, attitudes, and practice of community pharmacists regarding prescribing complementary supplements and/or non-prescription medications to overweight and obese patients.

\section{Materials and Methods Study Design}

This is a cross-sectional questionnaire-based self-administrative study that was conducted across community pharmacies in Aseer region.

\section{Sample Size and Sampling Technique}

The questionnaire was randomly distributed to 90 community pharmacies in six major cities in Aseer region (Abha, Khamis Mushait, Mahayel, Sarat Abeeda, Ahad-Rufaida, and Bishah). The number of registered community pharmacists in Aseer region who were eligible to answer the study's survey was 747 pharmacists. ${ }^{21}$ Using the sample size calculation formula, the number of participants was 224 with $95 \%$ confidence interval and $5 \%$ margin of error.

$$
n=\frac{Z^{2} p(1-p)}{d^{2}}
$$

Where; $n=$ sample size, $Z=Z$ statistic for a level of confidence ( $\mathrm{Z}=1.96$ is selected many literatures to give a good power in estimation the sample size), $p=$ expected prevalence or proportion.

Out of 221 pharmacists, 191 completed the survey $(86.4 \%$ response rate). The questionnaire was written in English and handed to the pharmacist(s) in each pharmacy by a Doctor of Pharmacy (PharmD) interns (data collectors). The pharmacists were approached during daytime business hours. The pharmacists were asked to voluntarily participate in the study and given enough time to complete the survey. The investigators explained the objectives of the study to the pharmacists and assured them that their individual-level data regarding their experience, knowledge, and attitudes would neither be published nor passed on to anyone else. The data collection took place over 5 weeks between 25/03/2019 and 25/05/2019.

The risk of bias was diminished by the random selection of pharmacies and the processes to ensure participant anonymity (their identification was kept confidential, private data were not asked for, and responses were blindly pooled after ensuring questionnaire completeness).

\section{Questionnaire}

No previous studies were found to assess the knowledge, attitudes, and practice of community pharmacists towards prescribing of weight reducing products. Therefore, a panel of three academics and a family medicine consultant developed the questionnaire and the validation process included a pilot study involving four academics and ten community pharmacists. These initial data were not included in the results analysis. Then, the internal consistency (reliability) of the questionnaire was evaluated for 12 items (attitudes and practice questions) where the responses will be taken on 5-points Likert scale. From the 14 participants (pilot study), the standard deviation and variances were calculated for each item and overall for all items. The Chronbach alpha was calculated using the formula:

$$
\text { Chronbach alpha }=\frac{K}{K-1} * \frac{S i j^{2}-\sum S i^{2}}{S i j^{2}}
$$


where $K$ is the number of items (questions), $S i j^{2}$ is the overall variance, and $\sum S i^{2}$ is the sum of items variances. The internal consistency of the questionnaire was 0.787 .

The questionnaire consisted of 26 questions on 4 domains; (Domain I: 8 questions related to demographics; Domain II: 6 questions on knowledge, with open and closed type questions; and Domains III and IV: 6 questions per domain related to the attitudes and practice of community pharmacists regarding prescribing weight reduction agents and supplements). The attitudes and practices were examined using a 5-point Likert scale $(5=$ strongly agree, $4=$ agree, $3=$ neutral, $2=$ disagree, and $1=$ strongly disagree) to assess the extent to which the pharmacists agree or disagree with the statements related to weight reduction drugs and herbal supplements.

\section{Ethical Considerations}

Ethical approval for this study was granted by the regional ethical committee in Aseer region (REC \# 2018-06-23). All participants were asked for consent before starting the questionnaire.

\section{Statistical Analysis}

The questionnaires were reviewed for completeness and accuracy and the data were cleaned, coded, and then entered into SPSS version 20 (IBM Corp., Armonk, NY, USA). The sociodemographic data were analyzed using descriptive analysis. Categorical variables were reported as frequencies and percentages, and continuous variables were represented as means and standard deviations. The mean scores and standard deviations were calculated for each statement based on the 5-point Likert scale responses (indicating strongly agree, agree, neutral, disagree, and strongly disagree, respectively). Subsequently, the Likert scale responses were collapsed into three categories (agree, neutral, and disagree) and the pooled mean and standard deviation for agreement, neutral, and disagreement were assessed to present the responses more clearly.

\section{Results}

\section{Respondents' Sociodemographic Characteristics}

Most of the respondents were males (98\%) and most were 20-40 years old (173 out of 191 participants). Most of the participants were holding Bachelor of Pharmacy degree with less than 5-year experience ( $80 \%$ and $75.39 \%$, respectively). The most commonly prescribed weight-reducing agent was green tea followed by oatmeal products and then ginseng. Sociodemographic characteristics are summarized in Table 1.

\section{Respondents' Knowledge Regarding Weight Reduction Agents}

Table 2 shows the community pharmacists' knowledge regarding the main weight reduction agents' basic information. Almost $85 \%$ of the respondents did not know which weight reduction agents are US Food and Drug Administrationapproved OTC products. The highest percentage of correct

Table I Sociodemographic Characteristics of Participants

\begin{tabular}{|c|c|c|}
\hline Variable & $\mathbf{n}$ & $\%$ \\
\hline \multicolumn{3}{|l|}{ Gender } \\
\hline Male & 187 & 98 \\
\hline Female & 4 & 2 \\
\hline \multicolumn{3}{|l|}{ Age } \\
\hline $20-30$ & 74 & 38.74 \\
\hline $31-40$ & 99 & 51.83 \\
\hline $4 I-50$ & 16 & 8.37 \\
\hline$>50$ & 2 & 1.04 \\
\hline \multicolumn{3}{|l|}{ Education Level } \\
\hline Diploma (pharmacy technician) & 10 & 5.23 \\
\hline Bachelor of Pharmacy (BSc Pharm) & 153 & 80.10 \\
\hline Doctor of Pharmacy (PharmD) & 24 & 12.56 \\
\hline Postgraduate degree (master's degree or $\mathrm{PhD}$ ) & 4 & 2.09 \\
\hline \multicolumn{3}{|l|}{ Years of Pharmacy Experience } \\
\hline$<1$ & 6 & 3.14 \\
\hline $1-3$ & 144 & 75.39 \\
\hline $3-6$ & 27 & 14.13 \\
\hline $6-10$ & 11 & 5.75 \\
\hline$>10$ & 3 & 1.57 \\
\hline \multicolumn{3}{|l|}{ Pharmacy Location } \\
\hline Rural & 18 & 9.42 \\
\hline Urban & 173 & 90.57 \\
\hline \multicolumn{3}{|l|}{ Commonly Prescribed Weight Reduction Products } \\
\hline Green tea & 137 & 71.7 \\
\hline Oatmeal products & 70 & 36.7 \\
\hline Ginseng & 41 & 21.4 \\
\hline Green coffee bean extract & 38 & 20 \\
\hline Metformin & 26 & 13.7 \\
\hline Orlistat $60^{\circledR}$ & 13 & 6.8 \\
\hline Others (ginger, ginkgo, protein bars, garcinia) & 8 & 4.2 \\
\hline \multicolumn{3}{|l|}{$\begin{array}{l}\text { Are You Aware of the Products That Could Be Used } \\
\text { for Weight reduction? }\end{array}$} \\
\hline Yes & 182 & 95.28 \\
\hline No & 9 & 4.71 \\
\hline \multicolumn{3}{|l|}{ Have You Seen a Patient Complaining of Side Effect(s) } \\
\hline \multicolumn{3}{|l|}{ After Using Weight Reduction Product(s)? } \\
\hline Yes & 3 & 1.57 \\
\hline No & 188 & 98.43 \\
\hline
\end{tabular}


Table 2 Community Pharmacists' Knowledge About Main Weight Reduction Products

\begin{tabular}{|l|l|l|}
\hline Knowledge Item & $\begin{array}{l}\text { Correct } \\
\text { Answer, } \\
\mathbf{n}(\%)\end{array}$ & $\begin{array}{l}\text { Incorrect } \\
\text { Answer, } \\
\text { n (\%) }\end{array}$ \\
\hline $\begin{array}{l}\text { US Food and Drug } \\
\text { Administration-approved OTC } \\
\text { agents } \\
\text { for weight reduction }\end{array}$ & $29(15.2)$ & $162(84.8)$ \\
\hline $\begin{array}{l}\text { Naloxone/bupropion (Contrava } \\
\text { dosage form }\end{array}$ & $67(35.1)$ & $124(64.9)$ \\
\hline Orlistat ${ }^{\circledR}$ I20 common side effects & $94(49.2)$ & $97(50.8)$ \\
\hline $\begin{array}{l}\text { Liraglutide (Saxenda }{ }^{\circledR} \text { ) maximum } \\
\text { daily dose }\end{array}$ & $75(39.3)$ & $116(60.7)$ \\
\hline $\begin{array}{l}\text { Green tea and garcinia adverse } \\
\text { effects and drug interactions }\end{array}$ & $46(24.1)$ & $145(75.9)$ \\
\hline $\begin{array}{l}\text { Metformin is an OTC drug for } \\
\text { weight reduction }\end{array}$ & $105(55)$ & $86(45)$ \\
\hline
\end{tabular}

answers was for the statement regarding whether metformin is prescribed as an OTC weight reduction agent. Regarding the other knowledge questions, more than $50 \%$ of the participants provided incorrect answers.

\section{Respondents' Attitudes Regarding Weight} Reduction Agent Use

More than half of the participants believed that weight reduction agents are safe and effective but may not show true improvement in obese patients. However, $64.91 \%$ of the participants would limit weight reduction agents to obese patients who could not reduce their weight through exercise and diet. Most of the participants (84.81\%) agreed that community pharmacists should advise patients regarding the best way to reduce their weight. More than $80 \%$ of the pharmacists agreed that knowledge and continuous education regarding weight reduction products are crucial both for community pharmacists and patients (Table 3).

\section{Participants' Responses About Weight Reduction Product Prescribing Practices}

Seventy-five percent of the participants regularly dispense weight reduction products without prescription. Furthermore, more than two-thirds of the participants think that the dispensed weight reduction products show efficacy regarding weight reduction. Moreover, more than $80 \%$ of the participants agreed that it is very important to counsel patients regarding dispensed weight loss products, and more than $80 \%$ also agreed that pharmacists should regularly discuss weight reduction products with other healthcare professionals. Table 4 summarizes the participants' responses regarding prescribing weight reduction products.

\section{Discussion}

To the best of our knowledge, this study is the first study in Saudi Arabia to assess the knowledge and attitudes of community pharmacists regarding weight reduction products. This study shows an enormous lack of knowledge

Table 3 Community Pharmacists' Attitudes Regarding Prescribing Weight Reduction Products

\begin{tabular}{|c|c|c|c|c|}
\hline Attitude Item & $\begin{array}{l}\text { Strongly Agreel } \\
\text { Agree, } n(\%)\end{array}$ & $\begin{array}{l}\text { Neutral, } \\
\text { n (\%) }\end{array}$ & $\begin{array}{l}\text { Strongly Disagree/ } \\
\text { Disagree, } \mathbf{n}(\%)\end{array}$ & $\begin{array}{l}\text { Mean } \pm \text { SD } \\
(95 \% \mathrm{Cl})\end{array}$ \\
\hline Weight reduction agents are effective and safe & $112(58.68)$ & $58(30.36)$ & $21(10.99)$ & $\begin{array}{l}3.51 \pm 0.38 \\
(3.46-3.56)\end{array}$ \\
\hline $\begin{array}{l}\text { Community pharmacists should be able to advise patients regarding the best } \\
\text { way to safely reduce weight }\end{array}$ & $162(84.8 I)$ & $16(8.37)$ & $13(6.80)$ & $\begin{array}{l}4.06 \pm 0.49 \\
(3.99-4.13)\end{array}$ \\
\hline $\begin{array}{l}\text { Counseling of the patient regarding using any weight reduction product is } \\
\text { crucial }\end{array}$ & $135(70.68)$ & $35(18.32)$ & $21(10.99)$ & $\begin{array}{l}3.82 \pm 0.30 \\
(3.68-3.96)\end{array}$ \\
\hline $\begin{array}{l}\text { Weight reduction products should be limited to obese patients who could not } \\
\text { reduce their weight by exercise and diet }\end{array}$ & $124(64.91)$ & $22(11.52)$ & $45(23.56)$ & $\begin{array}{l}3.59 \pm 0.31 \\
(3.55-3.63)\end{array}$ \\
\hline $\begin{array}{l}\text { Knowledge and continuous education on weight reduction products is crucial } \\
\text { for community pharmacists }\end{array}$ & $168(87.94)$ & $13(6.80)$ & $10(5.24)$ & $\begin{array}{l}4.19 \pm 0.60 \\
(4.1-4.28)\end{array}$ \\
\hline $\begin{array}{l}\text { If I were an obese patient, I would be knowledgeable regarding what products } \\
\text { may reduce weight in a safe way }\end{array}$ & $164(85.85)$ & II (5.75) & $16(8.37)$ & $\begin{array}{l}4.08 \pm 0.44 \\
(4.04-4.14)\end{array}$ \\
\hline
\end{tabular}

Notes: The 5-point Likert scale results were collapsed into strongly agree/agree, neutral, and strongly disagree/disagree.

Abbreviations: SD; standard deviation, $\mathrm{Cl}$; confidence interval. 
Table 4 Community Pharmacists' Responses Regarding Prescribing Weight Reduction Products

\begin{tabular}{|c|c|c|c|c|}
\hline Practice Item & $\begin{array}{l}\text { Strongly } \\
\text { Agree/Agree, } \\
\text { n (\%) }\end{array}$ & $\begin{array}{l}\text { Neutral, } \\
\text { n (\%) }\end{array}$ & $\begin{array}{l}\text { Strongly } \\
\text { Disagree/ } \\
\text { Disagree, n (\%) }\end{array}$ & $\begin{array}{l}\text { Mean } \pm \text { SD } \\
(95 \% \mathrm{Cl})\end{array}$ \\
\hline $\begin{array}{l}\text { Pharmacist regularly dispenses weight reduction products without } \\
\text { prescription }\end{array}$ & 144 (75.39) & $36(18.84)$ & II (5.75) & $\begin{array}{l}3.89 \pm 0.53 \\
(3.81-3.97)\end{array}$ \\
\hline The dispensed drugs show efficacy regarding weight reduction & $134(70.15)$ & $40(20.09)$ & $17(8.89)$ & $\begin{array}{l}3.73 \pm 0.50 \\
(3.66-3.80)\end{array}$ \\
\hline $\begin{array}{l}\text { Pharmacist should have enough time to counsel the patients regarding the } \\
\text { dispensed weight reduction products }\end{array}$ & $166(86.90)$ & $10(5.23)$ & $15(7.85)$ & $\begin{array}{l}3.95 \pm 0.46 \\
(3.88-4.02)\end{array}$ \\
\hline $\begin{array}{l}\text { Pharmacist should regularly discuss weight reduction products with other } \\
\text { healthcare professionals }\end{array}$ & $155(81.14)$ & $22(11.5 I)$ & $14(7.33)$ & $\begin{array}{l}3.97 \pm 0.42 \\
(3.91-4.03)\end{array}$ \\
\hline $\begin{array}{l}\text { Pharmacists are concerned about the safety of patients who uses drugs } \\
\text { for weight reduction }\end{array}$ & $149(78.00)$ & $25(13.09)$ & 17 (8.89) & $\begin{array}{l}3.88 \pm 0.49 \\
(3.81-3.95)\end{array}$ \\
\hline $\begin{array}{l}\text { Willingness to know more about the best practice for weight reduction } \\
\text { using weight reduction products or other measures }\end{array}$ & $170(89.00)$ & $10(5.23)$ & II (5.75) & $\begin{array}{l}4.20 \pm 0.58 \\
(4.12-4.28)\end{array}$ \\
\hline
\end{tabular}

Notes: The 5-point Likert scale results were collapsed into strongly agree/agree, neutral, and strongly disagree/disagree.

Abbreviations: SD; standard deviation, $\mathrm{Cl}$; confidence interval.

among community pharmacists in Aseer region regarding weight reduction products and supplements. These results concur with the results of a study of community pharmacists in Australia, in which the participants were not able to identify the adverse effects and drug interactions of commonly used weight reduction products (green tea, chromium, and garcinia). ${ }^{22}$ These findings could be due to the lack of continuous education for community pharmacists. Furthermore, community pharmacists should be aware of the herbal drug interactions when they prescribe/ provide advice regarding any weight reduction agents, especially for patients with concomitant chronic diseases such as hypertension and diabetes. Another study was conducted in Eastern region of Saudi Arabia showed similar results were the green tea was the most commonly used weight-reducing agent. ${ }^{23}$

However, the participating pharmacists had positive attitudes toward the safety and efficacy of weight reduction products. This is going along with other studies that exhibited positive attitudes of community pharmacists towards using herbal remedies and nutraceutical products by Saudi and Kuwaiti populations. ${ }^{21,24}$ Although community pharmacists in western countries were able to participate effectively and efficiently in weight management, ${ }^{25-27}$ community pharmacists in the Middle East may not be able to provide the same service for obese patients due to many reasons such as the lack of trust in community pharmacists and barriers hindering obesity counseling. ${ }^{28}$
In this study, pharmacists believed that patient counseling regarding weight reduction products is very important. Moreover, pharmacists believed that they should discuss the safety and efficacy of the products with other healthcare providers to update their knowledge and improve public health.

This was a cross-sectional study in Aseer region, Saudi Arabia. Even though the response rate to the survey was excellent (88\%) and a large number of pharmacists (191) participated in the study, the generalization of the results to community pharmacists in other areas of Saudi Arabia is unclear, and more studies should be conducted in larger and more population-dense regions. In addition, we recommend that pharmacists should undergo continuous education and training to be able to provide their patients with accurate and optimal care.

\section{Conclusion}

This study showed that most of the respondents believe that increasing their knowledge regarding weight reduction products and having enough time to counsel the patients is important to improve the overall public health outcomes. However, the lack of basic knowledge regarding weight reduction products was noticeable; therefore, conducting more educational seminars and workshops is crucial to ensure basic knowledge among community pharmacists. Community pharmacists exhibited positive attitudes when it comes to the safety of weight reducing products. However, dispensing 
weight reducing products should be minimal and under mutual supervision of endocrinologists and pharmacists. The patient counseling is an important measure that should be taken into consideration to ensure appropriateness of medication use and patient safety. Moreover, the regulatory authorities should keep an eye on the provision of drugs and herbal products for obese patients without medical prescriptions.

\section{Acknowledgments}

The author would like to acknowledge the administrative and technical support provided by King Khalid University. In addition, the author would like to thank the research team at the College of Pharmacy for helping with data collection from the designated pharmacies.

\section{Author Contributions}

The author contributed to data analysis, drafting or revising the article, gave final approval of the version to be published, and agree to be accountable for all aspects of the work.

\section{Disclosure}

There are no conflicts of interest to declare related to this work.

\section{References}

1. World Health Organization. Obesity and overweight. Fact sheet N 311; 2011. Available from: http://www.who.int/mediacentre/factsheets/ fs311/en/. Accessed August 19, 2011.

2. James WPT, Jackson-Leach R, Mhurchu $\mathrm{CN}$, et al. Overweight and obesity (high body mass index). In: Ezzati M, Lopez AD, Rodgers A, Murray CJL, editors. Comparative Quantification of Health Risks: Global and Regional Burden of Disease Attributable to Selected Major Risk Factors. Geneva: World Health Organization; 2004:497-596.

3. Yang P, Zhou Y, Chen B, et al. Overweight, obesity and gastric cancer risk: results from a meta-analysis of cohort studies. Eur J Cancer. 2009;45(16):2867-2873. doi:10.1016/j.ejca.2009.04.019

4. Freedland SJ, Wen J, Wuerstle M, et al. Obesity is a significant risk factor for prostate cancer at the time of biopsy. Urology. 2008;72:1102-1105. doi:10.1016/j.urology.2008.05.044

5. Nguyen NT, Magno CP, Lane KT, Hinojosa MW, Lane JS. Association of hypertension, diabetes, dyslipidemia, and metabolic syndrome with obesity: findings from the National Health and Nutrition Examination Survey, 1999 to 2004. J Am Coll Surg. 2008;207:928-934. doi:10.1016/j.jamcollsurg.2008.08.022

6. DeNicola E, Aburizaiza OS, Siddique A, Khwaja H, Carpenter DO. Obesity and public health in the Kingdom of Saudi Arabia Rev. Environ Health. 2015;30(3):191-205.

7. Balbo L Saudi Arabia's fast food boom is finger lickin' awful. Green Prophet; 2012. Available from: www.greenprophet.com/2012/04/ saudi-arabia-fast-food. Accessed August 19, 2011.

8. Al-Haqwi A, Al-Nasir M, Ahmad N, Masaudi E, Alotaibi S, Bashir A. Obesity and overweight in a major family practice center, central region, Saudi Arabia. Saudi J Obes. 2015;3:12. doi:10.4103/23472618.158690
9. Al-Nuaim AR. Population-based epidemiological study of the prevalence of overweight and obesity in Saudi Arabia, regional variation. Ann Saudi Med. 1997;17:195-199. doi:10.5144/0256-4947.1997.195

10. Ríos-Hoyo A, Gutiérrez-Salmeá G. New dietary supplements for obesity: what we currently know. Curr Obes Rep. 2016;5:262-270.

11. Food and Drug Administration. Dietary supplement health and education act of 1994. US Department of Health and Human Services; 1994. Available from: http://www.fda.gov/RegulatoryInformation/ Legislation/FederalFoodDrugandCosmeticActFDCAct/ SignificantAmendmentstotheFDCAct/ucm148003.htm\#sec3.

Accessed August 19, 2011.

12. Food and Drug Administration. What is a dietary supplement? 2015. Available from: http://www.fda.gov/AboutFDA/Transparency/Basics/ ucm195635.htm. Accessed August 19, 2011.

13. Geller A, Shehab N, Weidle N, et al. Emergency department visits for adverse events related to dietary supplements. $N$ Engl J Med. 2015;373:1531-1540. doi:10.1056/NEJMsa1504267

14. Al-Rowais NA. Herbal medicine in the treatment of diabetes mellitus. Saudi Med J. 2002;23(11):1327-1331.

15. Eldalo AS, Alotaibi MN, Alenazi TO, Albogami HA, Mohamed KM. Use of herbal medicines in the treatment of obesity in Taif, Saudi Arabia. Saudi J Med Med Sci. 2017;5:149.

16. Alhazzani AA, Alqahtani AM, Abouelyazid A, et al. Public awareness, knowledge, and attitudes toward epilepsy in the Aseer region, Saudi Arabia - A community-based cross-sectional study. Epilepsy Behav. 2016;63:63-66. doi:10.1016/j.yebeh.2016.07.041

17. Alshahrani SM, Alavudeen SS, Alakhali KM, Al-Worafi YM, Bahamdan AK, Vigneshwaran E. Self-medication among king Khalid University students, Saudi Arabia. Risk Manag Healthc Policy. 2019;12:243-249. doi:10.2147/RMHP.S230257

18. Andronicou A-M, Krska J, Hackett A, Richards J. Supply of overthe-counter weight-loss products from community pharmacies. Int J Pharm Pract. 2009;17:333-337. doi:10.1211/ijpp.17.06.0003

19. George K, Lovelady C, Connolly D, Parmar S, Davies MJ. Community pharmacy contribution to weight management: identifying opportunities. Int J Pharm Pract. 2010;18:7-12. doi:10.1211/ijpp.18.01.0003

20. Royal Pharmaceutical Society of Great Britain. Practice guidance: obesity and overweight. Pharm J. 2005;274:435-436.

21. Alsayari A, Almghaslah D, Khaled A, et al. Community pharmacists' knowledge, attitudes, and practice of herbal medicines in Asir Region, Kingdom of Saudi Arabia. Evid Based Complement Alternat Med. 2018;2018:1568139. doi:10.1155/2018/1568139

22. Taing M, Clavarino AM, McGuire TM. Australian community pharmacists' knowledge of popular herbal/nutrient weight-loss complementary medicines. $J$ Pharm Pract Res. 2017;47:463-470. doi:10.1002/jppr.1313

23. Ahmad W, Ahmad A, Ali MD, et al. A questionnaire-based study for weight loss by using herbal drugs in Dammam (Eastern Region), Kingdom of Saudi Arabia. J Pharm Bioallied Sci. 2019;11 (3):248-253. doi:10.4103/jpbs.JPBS_102_19

24. Abahussain NA, Abahussain EA, Al-Oumi FM. Pharmacists' attitudes and awareness towards the use and safety of herbs in Kuwait. Pharm Pract (Granada). 2007;5(3):125-129. doi:10.4321/S188636552007000300005

25. National Public Health Service for Wales. Weight management interventions by community pharmacists: a rapid review of the evidence; 2009. Available from: http://www2.nphs.wales.nhs.uk:8080/pharma ceuticalphtdocs.nsf/Main\%20Frameset?OpenFrameSet $\% 26$ Frame= Right \% 26; S r c = \% 2 F pharmaceuticalphtdocs.nsf\% 2 F 1 f 8687 d 8 da 97650980256 fa 30051 b 0 be $\%$ 2Fd694bf1 fb94bddbc8025756e004068f1\%3FOpenDocument\% 26AutoFramed. Accessed August 19, 2011.

26. Lloyd KB, Thrower MR, Walters NB, Krueger KP, Stamm PL. Evans RL Implementation of a weight management pharmaceutical care service. Ann Pharmacother. 2007;41:185-192. doi:10.1345/aph.1 E466 
27. Morrison D, McLoone P, Broshnahan N, McCombie L, Smith A, Gordon J. A community pharmacy weight management programme: an evaluation of effectiveness. BMC Public Health. 2013;13:282. doi:10.1186/1471-2458-13-282
28. Awad A, Waheedi M. Community pharmacists role in obesity treatment in Kuwait: a cross-sectional study. BMC Public Health. 2012;12:863. doi:10.1186/1471-2458-12-863

\section{Publish your work in this journal}

Risk Management and Healthcare Policy is an international, peerreviewed, open access journal focusing on all aspects of public health, policy, and preventative measures to promote good health and improve morbidity and mortality in the population. The journa welcomes submitted papers covering original research, basic science, clinical \& epidemiological studies, reviews and evaluations, guidelines, expert opinion and commentary, case reports and extended reports. The manuscript management system is completely online and includes a very quick and fair peer-review system, which is all easy to use. Visit http://www.dovepress.com/testimonials.php to read real quotes from published authors.

Submit your manuscript here: https://www.dovepress.com/risk-management-and-healthcare-policy-journal 